\title{
BREVES NOTAS SOBRE A FICÇÃO FOLCLÓRICA NO BRASIL ${ }^{1}$
}

Andriolli de Brites da Costa (UFRGS)

Recebido em 21 jun 2018. Andriolli de Brites da Costa é Doutorando no Programa Aprovado em 21 set 2018. de Pós-Graduação em Comunicação e Informação. Produção bibliográfica: COSTA, Andriolli; DE CARLI, Anelise. O Retrato da Lenda - Fotojornalismo e Mistério no Imaginário Farroupilha. Revista Internacional de Folkcomunicação, v.14, p.26, 2016; COSTA, Andriolli. A Mulher do Padre - Tradição e misoginia na adaptação audiovisual do mito da mula sem cabeça. In XXXX Congresso Brasileiro de Ciências da Comunicação, 2017, Curitiba. São Paulo: Intercom, 2017. v. 40. p.1-14. COSTA, Andriolli. Por que as notícias de mito e lenda são como são? In XII ALAIC, 2014, LIMA, Peru. ALAIC, 2014. Integrante do Grupo de Pesquisa Imaginalis. Vencedor do prêmio Freitas Nobre de melhor artigo em doutorado de Comunicação pelo Intercom (2017). Áreas de interesse: Comunicação; Jornalismo; Folclore Brasileiro; Imaginário; Mitologias. CV Lattes: http:// lattes.cnpq.br/6790145893762562. E-mail: andriolli_ costa@hotmail.com.

Resumo: Este artigo busca primeiramente estabelecer uma demarcação acadêmica para a ficção folclórica enquanto subgênero da ficção especulativa, distinguindo-a meramente de uma literatura regionalista ou de outras tentativas de 
nomenclatura contemporâneas. Traz ainda reflexões e apontamentos para delinear as potencialidades e desafios com os quais esta se depara na cena nacional de literatura fantástica. Para tanto, iniciamos explorando e problematizando o conceito de folclore, e em seguida construímos as aproximações entre a literatura fantástica brasileira e os temas da cultura popular desde o Romantismo do século XIX e seus ímpetos de valoração da tradição até o Fantasismo contemporâneo, no qual os mitos e lendas servirão de mote para desbravar esse Brasil fantástico ainda tão pouco explorado.

Palavras-chave: Ficção Folclórica; Folclore Brasileiro; Fantasia; Monteiro Lobato.

Abstract: This article firstly aims to establish an academic demarcation for Folkloric Fiction as a Speculative Fiction subgenre, distinguished from "Regional Literature" and other contemporary nomenclature attempts. It also brings notes and reflections in order to delineate the potentialities and challenges faced by Folkloric Fiction in the national scene of the Fantastic Literature. To that end, we explore and problematize the concept of folklore. Then, we construct the approximations between Brazilian Fantastic Literature and the folk culture themes, from the $19^{\text {th }}$ century Romanticism - and its utmost desire to value tradition - to the contemporary Fantasysm, in which myths and legends became the motto to discover this fantastic and yet unexplored Brazil.

Keywords: Folkloric Fiction; Brazilian Folklore; Fantasy; Monteiro Lobato.

\section{INTRODUÇÃO}

Este artigo, de início, abraça dois principais objetivos. O primeiro deles é estabelecer uma demarcação acadêmica para 
a Ficção Folclórica enquanto subgênero da ficção especulativa - englobando, desta maneira, produções que vão da Fantasia ao Terror e à Ficção Científica. Com isso, buscamos distinguir o termo meramente de uma "literatura regionalista" ou de outras tentativas de nomenclatura contemporâneas. O segundo é, após traçar um marco histórico para seu surgimento e consolidação, delinear potencialidades e desafios com os quais esta se depara na cena nacional de literatura fantástica contemporânea.

Ainda que de alguma maneira organizador, não é nosso objetivo estabelecer manuais de conduta ou regras normativas. Este é um trabalho inicial de diagnose em uma área que, ela própria, ainda está em plena efervescência. Mais que delinear um terceiro objetivo, temos também uma expectativa de que esses apontamentos possam estimular outros pesquisadores a voltarem seus olhos para a Ficção Folclórica brasileira, acompanhando essa movimentação tão específica dentro do campo do insólito.

Para tanto, cabe delinear o percurso que será percorrido ao longo do trabalho. De início trataremos das interfaces entre literatura e folclore brasileiro, das reticências do final do século XIX ao seu encontro com os modernistas do século XX. Em seguida, exploraremos as distinções entre literatura regionalista, fantasia rural e outras tentativas de nomenclatura não exatamente conceituais, como a "borduna e feitiçaria" de Roberto de Sousa Causo e a "fantasia de registro folclórico" de Simone Saueressig. Discutiremos então as peculiaridades da ficção folclórica em relação à sua temática, à pauta nacionalista e à alteridade para com o Brasil retratado, permeando os apontamentos com casos exemplares que permitam dar a ver o que for levantado. 


\section{FOLCLORE E FANTASIA NO SÉCULO XIX}

Ao nos propormos aqui a falar de uma ficção folclórica, cabe de imediato explorar o que é folclore. Ou ao menos de que folclore é este que estamos falando. O termo vem de um neologismo britânico, folk lore, o saber do povo, popularizado a partir da coluna homônima publicada por William John Thoms no periódico The Athenauem, que teve sua estreia em 22 de agosto de 1846. É por isso que até hoje a data é celebrada internacionalmente como Dia do Folclore.

Cabe ressaltar, é claro, que mesmo com uma data de nascimento oficial para o termo "folclore", os modos e costumes de tempos passados, bem como suas crenças e superstições sempre foram objeto de interesse. Se não de um braço dos estudos antropológicos, havia já os que se voltavam para as chamadas "antiguidades populares" ou "literaturas populares" - sendo essa literatura, evidentemente, não-escrita, mas oral. Transmitida a partir de baladas, cantos e outras formas de comunicação e memória baseadas na oralidade e na performance ${ }^{2}$.

William John Thoms foi antes de tudo um antiquário, e muito por conta disso criou-se um estigma sobre os que se denominavam folcloristas como meros colecionadores de memorabílias do passado; curadores de um museu de curiosidades anacrônicas. Suas preocupações encontraram eco no Romantismo alemão (Thoms ficara especialmente encantado pela Deutsche Mythologie de Jacob Grimm) e no florescimento dessa corrente no século XIX, tudo o que substitui a produção literária para a população iletrada. Sabemos hoje que oralidade não se opõe à escrita, mas que ambos se entrecruzam, se transformam e se complementam. Ver, por exemplo, Performance, Recepção, Leitura (ZUMTHOR, 2014). 
que começa a despertar a paixão pelos saberes tradicionais em oposição ao progressismo da modernidade.

Anos depois, refletindo sobre o que o motivou a sugerir a criação da coluna Folk-Lore ao editor da revista, Thoms recorda o contexto: a febre das ferrovias estava em seu ápice, o "cavalo de ferro" solapava o passado sobre seus cascos, "fazendo as relíquias de nossa primitiva mitologia popular levantarem voo". (Thoms, Apud EMRICH, 1946, p.360). Era mister tomar notas sobre costumes do velho mundo, práticas e superstições populares, antes que tudo se esvanecesse.

Não houve uma preocupação por parte de Thoms em conceituar o termo. Acreditava ele que os leitores entendiam perfeitamente o que pretendia dizer: "folclore era um termo genérico englobando uma grande variedade de temáticas ligadas à tradição que anteriormente eram encarados com pouca seriedade pelos estudos acadêmicos." (EMRICH, 1946, p.364).

Como lembra Otto Groth, uma Ciência não se constitui pela exclusividade do seu objeto de interesse, mas sim pela peculiaridade do olhar que se lança sobre ele; pelos novos "modos de contemplação" (2011, p.33). Da mesma forma, nenhum termo se basta academicamente a partir da primeira vez em que é mencionado, mas sim pelo corpo reflexivo que se constrói a partir dele. E a Ciência do Folclore avançou muito conceitualmente nestes mais de 170 anos de sua criação. A começar, por exemplo, por uma inquietação fundamental: Quem é o povo presente no folk? Nos registros iniciais fica claro o distanciamento construído entre os saberes instituídos e o saber campesino, onde o intelectual se 
distingue do povo - os pobres - e seus abusões sem uma devida relação de alteridade. Hoje, compreende-se que todo grupo social pode ser considerado povo, desde que compartilhe algo no emaranhado dessa rede da tradição. Resume Cascudo:

Todos os países do mundo, raças, grupos humanos, famílias, classes profissionais, possuem um patrimônio de tradições que se transmite oralmente e é defendido e conservado pelo costume. Esse patrimônio é milenar e contemporâneo. Cresce com os conhecimentos diários desde que se integrem nos hábitos grupais, domésticos ou nacionais. Esse patrimônio é o FOLCLORE. Folk, povo, nação, família, parentalha. Lore, instrução, conhecimento na acepção da consciência individual do saber. Saber que sabe. Contemporaneidade, atualização imediadista do conhecimento. (CASCUDO, 1967, p.9)

Algo que fica claro em Cascudo e nos folcloristas do século XX é que folclore perde a relação de algo puramente ligado ao passado para se vincular ao presente. É cultura viva, mutante e mutável que continua a se transformar para permanecer sempre presente na vida de uma comunidade. Como propõe Rossini Tavares de Lima (2003), se uma manifestação cultural popular não faz mais sentido deixa de ser folclórica, passa a integrar a "história do folclore". Gênese disso esteve no próprio trabalho de Thoms, que sempre incentivou a pesquisa etnográfica e o ato presencial, e não a recolha a partir de livros (EMRICH, 1946). Folclore é proximidade, e essa relação só foi se tornando mais próxima conforme sujeitos e objetos se entremearam.

Outra controvérsia que deve ser assinalada é quanto ao uso de folclore ou cultura popular. É comum ouvir pessoas que são 
reticentes ao uso do primeiro termo por este estar muito vinculado a um senso comum que o liga, na academia, a um saber menor e pré-científico, e fora dela a algo ligado a grupos interioranos, aos mais velhos ou às crianças ${ }^{3}$. Folclore aparece como algo que se aprende na escola, quando em verdade basta saber olhar para perceber que é fora dos espaços institucionalizados que esse saber tradicional floresce.

Preferem estes outros, portanto, "cultura popular", ignorando que o termo também cai na vulgata, confundindo-se à "cultura pop" e ao "popular massivo", para usar um termo de Martin-Barbero (2013). Em concordância com a UNESCO, a Carta do Folclore Brasileiro de 1995 estabelece os dois termos como sinônimos, e assim também o faremos neste texto.

O Romantismo alemão também se refletiu em terras brasileiras, mas não de maneiras singulares. Primeiramente com um Indianismo que vestiu o indígena de cavaleiro andante, a partir da segunda metade do século XIX, e mais tarde com um Sertanismo que faria o mesmo com o sertanejo, o peão, o caboclo. "Falsificando" nosso mato, como diz a crítica de Monteiro Lobato a Bernardo Guimarães (Apud BOSI, 1978, p.157). No que diz respeito ao bestiário folclórico, que em breve veremos ser o grande mote da ficção folclórica contemporânea, nossos olhos ainda estavam todos voltados para a Europa, levando a elite intelectual brasileira a construir uma imagética fantástica calcada nos temas igualmente estrangeiros. Falava-se de faunos e sereias, de grifos 30 português Teófilo Braga (1843-1924), um dos primeiros compiladores de narrativas folclóricas lusófonos e bastante influenciado pelo Positivismo de Comte, dizia que essas histórias se mantinham tenazes especialmente entre "raças atrasadas", "indivíduos mais adaptados à concepção mítica" (crianças) e nos quais "prepondera a memória histórica" (velhos). Ver (Braga Apud ROMERO, 1885, p.XV). 
e dragões. Estátuas de duendes barbaçudos, encapotados para o frio nibelungo debaixo de um sol tupiniquim, enfeitavam parques e praças de São Paulo.

Tal fato, já na primeira década do século XX, enervaria Lobato, o incentivando a publicar uma série de artigos que desembocariam, por um lado, em Saci Pererê - Resultado de um Inquérito (1918), e por outro em uma ampla defesa do folclore nacional como inspiração artística.

Se o medo e a escuridão, reflete Lobato, foram capazes de gerar tanto os deuses gregos imortalizados pelos aedos quanto a corte das fadas em sonhos preservados pela dramaturgia de Shakespeare; no Brasil, que em nada devia no quesito da fantástica popular, faltava ainda o envolvimento dos artistas para abraçar de vez essa cultura. Não apenas por desinteresse, mas por falta de acesso. Afinal, justifica o autor, se era comum encontrar tomos dos mais variados dedicados à mitologia celta nas bibliotecas públicas, o mesmo não pode ser dito dos livros sobre nosso folclore que raramente conspurcavam o nobre ambiente livresco. Para manter a honestidade do registro, Lobato recomendava ir ao povo; "afundar na roça para uma consulta ao grande livro não escrito da crendice popular" (2008, p.32).

Talvez aos olhos de hoje a assertiva de Lobato possa parecer banal. No entanto, é preciso lembrar que na época, especialmente nos periódicos dominados por uma elite intelectual excludente, tudo aquilo ligado ao folclórico era abordado pela perspectiva do exótico, pouco mais que um folhetim de curiosidades. Os leitores ofendiam-se em ver as páginas de importantes periódicos ocupadas com os modos simplórios do "povo" no qual não se enxergava como parte integrante. 
Basta ver, por exemplo, aquele que é considerado o primeiro artigo de jornal no qual o mito do Saci Pererê é mencionado. Publicado em 1859, no Correio Paulistano, o texto assinado apenas por "C."4 já se coloca na defensiva, justificando-se o tempo todo. $\mathrm{O}$ pedido de desculpas ao mesmo tempo em que apascenta o público, menospreza de início todo o conteúdo das narrativas que investiga.

Respeitável leitor, venerando crítico de testa enrugada e olhar inspirado, não vos revoltais contra as histórias populares que vou começar a escrever. São crenças errôneas e muitas vezes cômicas as do povo, mas nem por isso destituídas de interesse. Recream a imaginação, acalmam por vezes os cuidados do espírito e são para muitos uma recordação doce do passado. (...) Se assim for não diga ao ler o meu artigo - que pachorra! Por que todos nós temos nossas horas de descanso, e foi nelas que eu o escrevi. (CORREIO PAULISTANO, 1859, p.2).

É sempre nas horas de descanso que o devaneio toma conta, diríamos de uma maneira bachelardiana. Curioso é perceber que movimento semelhante passava aqueles que buscavam escrever sobre tudo aquilo que fugia da estética concreta e positiva do Realismo. Esse paralelo é facilmente identificável no caso de um dos maiores escritores brasileiros, Machado de Assis, que, com a consciência do desprestígio da literatura fantástica, advertia no prefácio de Histórias da meia-noite, em 10 de novembro de 1873:

Vão aqui reunidas algumas narrativas, escritas ao correr da pena, sem outra pretensão que não seja a de ocupar alguma sobra do precioso tempo do leitor. Não digo com isto que o gênero seja

4 Alfredo do Vale Cabral, em texto publicado originalmente em 1883, já levantava a suposição de que o autor desconhecido fosse em verdade Couto de Magalhães (CABRAL, 1978, p.21). 
menos digno da atenção dele, nem que deixe de exibir predicados de observação e de estilo. $O$ que digo é que estas páginas, reunidas por um editor benévolo, são as mais desambiciosas do mundo. (Apud BATALHA, 2013, p.20).

\section{FILHOS DE LOBATO E CRIAS DA ANTROPOFAGIA}

Enquanto os escritos apresentados acima faziam questão de abaixar a expectativa do leitor, como que pedindo permissão para entrar pela porta, Monteiro Lobato não fazia concessões. Pelo contrário, provocava o leitor, sentia-se desafiado por ele. Após seus primeiros artigos sobre a "mitologia brasílica", nos quais relembrava casos ouvidos sobre o Saci Pererê, alguns assinantes do jornal $O$ Estado de S. Paulo ficaram absolutamente indignados com o fato de um jornal sério gastar tinta e papel com "tão grosseira superstição popular, dessas que depõe contra os nossos créditos de civilizados perante as nações estrangeiras" (LOBATO, 2008, p.35). Em ironia, Lobato dedica todo o Inquérito sobre o Saci ao Trianon, região que elegeu como substrato da goma europeia na capital paulista, e ataca nominalmente sempre que pode a "parentela" dos leitores revoltados.

Seria uma incorreção fazer parecer que Monteiro Lobato foi o primeiro escritor a reunir o fantástico e o folclórico na literatura. Afinal, Inglês de Sousa já colocava botos para dançar a varsoviana em Contos Amazônicos em 1893. De mesmo modo, as primeiras edições de Lendas do Sul, de João Simões Lopes Neto, no Rio Grande do Sul, são publicadas em 1913, povoando a literatura gaúcha de boitatás incandescentes e princesas mouras tornadas em lagartixas mágicas. Lopes não fez mera coleta do folclore, mas o moldou em 
narrativa. Ainda assim, o escritor paulista representou um grande marco de transição nesta relação. Haja vista que até hoje, quando se fala em literatura e folclore, seja como referência ou recusa, Lobato é o primeiro a ser mencionado.

O conto Pedro Pichorra - que marca a primeira vez em sua literatura onde o Saci dá as caras -, foi escrito em 1910, mas só foi publicado na coletânea Cidades Mortas, cuja primeira edição é de 1919. Na história, um menino tem certeza de ter visto o Saci quando passava a cavalo à noite, e conta a história em terror para seu pai. Ao final, revela-se que o assustador duende era apenas o brilho dos vagalumes em uma pichorra d'água, o que garante o apelido do protagonista pelo resto de sua vida.

A construção narrativa do conto, que coloca o leitor neste cenário rural onde o lusco-fusco das horas mortas e a tradição moldam o próprio olhar, ainda não poderia ser considerada uma manifestação do Fantástico se fôssemos usar a terminologia de Todorov 5 . Conforme ela, o que teríamos, com a revelação quase cínica da inexistência do Saci, negando o acesso ao maravilhoso, seria o universo do Estranho. O Fantástico, por sua vez, só aconteceria no exato momento da hesitação, da incerteza entre real e maravilhoso (2008, p.37). E isso temos perfeitamente instituído em 1921, enfim, com a publicação de O Saci, parte da série O Sítio do Picapau Amarelo.

5 Numa das definições mais clássicas para o "Fantástico", Tzvetan Todorov (1939-2017) assim classifica as narrativas que trouxessem elementos sobrenaturais, mas cujo foco é a incerteza entre o real e o "imaginário". O Fantástico duraria apenas conforme durasse esta hesitação. Houvesse uma explicação lógica, a narrativa penderia ao "Estranho"; fosse a justificativa mágica, a narrativa vacilaria para o "Maravilhoso" (TODOROV, 2008). Entretanto, no sentido lato, Fantástico é utilizado para descrever qualquer tipo de narrativa que fuja ao Realismo do século XIX. Quando falamos em "fantástico" ao longo deste texto, nos identificamos mais com a sugestão de Matangrano e Tavares de, ao considerar tanto as classificações do mercado quanto as questões levantadas pela academia, compreender o termo enquanto aquilo ligado ao Insólito (2018, p.20). 
A hesitação se desenvolve toda no momento da captura do Saci, quando Pedrinho olha para a garrafa e nada vê além de um recipiente vazio. É apenas na "modorra", o estado em que nos encontramos entre dormindo e acordado, que o personagem passa a ver não apenas o Saci, mas também os demais mitos folclóricos que habitam as matas. Ao final do livro, quando pretende apresentar o perneta para a família, Pedrinho percebe que ele partiu sem chance de despedidas. O único indício de sua presença é um galhinho de miosótis deixado sobre seu travesseiro. É que o nome da planta em inglês, identificam as crianças, é "forget-me-not" - não me esqueças (1994, p.77).

O fenômeno Sitio do Picapau Amarelo é difícil de ser resumido em poucas linhas. Carregou muito do próprio empreendedorismo de Lobato, que acreditou no trabalho e no mercado, trabalhou na autopublicação, fundou editoras, reescrevia incessantemente, trocava correspondência com leitores infantis e nunca os subestimava. Mais do que tudo, Lobato criou no Sítio uma terra onde podiam coexistir não apenas animais da fauna brasileira e mitos e lendas do nosso folclore, mas contos da carochinha, mitos gregos, clássicos da literatura (muitos dos quais ele próprio era tradutor) e até mesmo personagens do cinema e dos desenhos animados. Era um universo fantástico uno, onde todos eram feitos da mesma matéria: histórias. E isso significava muito num contexto no qual, décadas antes, o lendário brasileiro era território inexplorado para as artes.

Se ainda é preciso de comprovações do impacto sociocultural do Sítio, nada sintetizaria melhor esse momento do que um dos depoimentos que Lobato transcreve no segundo tomo de $A$ Barca 
de Gleyre. Em 28 de março de 1943, já debilitado por suas duas prisões no governo Vargas, devastado pela morte de seus filhos, o escritor recebe a mensagem de uma fã, então adulta, que cresceu lendo seus livros. Após demonstrar a coragem que enviar aquela carta representou em uma vida de repressão, finaliza: "Se alguém me perguntasse qual a oitava maravilha do mundo, eu diria: a Emília, o seu criador, ou o Sitio do Picapau Amarelo, pois tudo se confunde" (1964, p.349).

A formação de várias gerações destes "filhos de Lobato", como os nomeia Penteado Filho (1997), não se bastou apenas nos livros. Ao longo das décadas, foram adaptações para teatro, o filme de Rodolfo Nanni (1951) - baseada na mais querida história, O Saci, histórias em quadrinho e, é claro, as várias adaptações para televisão, iniciando com a série para a TV Tupi entre 1952-1963; depois, em uma parceria Globo e TVE, com a série de 1977 - 1986 e, por fim, com a retomada pela Globo entre 2001-2007. Isso sem falar na série animada, exibida entre 2012-2016 pela Globo e pelo Cartoon Network.

Se somássemos todos os anos de exibição das adaptações seriadas audiovisuais, teremos 30 anos de Sítio em grandes redes de televisão nos últimos 66 anos. Isso, é claro, descontando as reprises no Canal Futura e Viva, os DVDs e as reproduções pelo YouTube. Uma média considerável que mostra a presença constante dessa obra, acompanhando gerações. Ocorre, entretanto, que a força do audiovisual se sobrepõe ao próprio texto fonte. Muitos atribuem a Lobato a "culpa" pela infantilização do folclore brasileiro, como se o escritor o tivesse despido de suas características mais controversas para adequação ao público de crianças. Mesmo o antropólogo 
Renato Queiroz, em Um Mito Bem Brasileiro, o acusa de ter "domesticado" o Saci nesse processo (1987).

Será que aqueles que tecem essa crítica conhecem Lobato a partir dos livros ou apenas a partir da série? Em O Saci, de 1921, o personagem título suga sangue de cavalos - qual um vampiro sertanejo, teme cruzes, bentinhos e orações, algo que sempre foi completamente excluído das versões audiovisuais. O Curupira, explica o narrador, tinha o costume de se transformar em um ente querido do caçador para causar a ilusão de ser morto por ele mesmo, sendo esse o maior de seus castigos (1994, p.46). A Mula sem Cabeça retratada na obra é uma mulher que cometeu necrofagia, comendo cadáveres de crianças recém-enterradas no cemitério (1994, p.55). Nada disso vai para o audiovisual.

É bem verdade que existem versões mais violentas do Saci. A própria capa de Saci Pererê - Resultado de um Inquérito, organizado por Lobato em 1918, mostra isso. Nela, temos um Saci com chifres torcidos, dentes pontiagudos e segurando um pedaço de pau. Lendo o livro, encontramos versões do duende em que ele castiga animais, especialmente cachorros, e bate mesmo em humanos que lhe negam fumo. No Inquérito temos sacis de todos os tipos e tamanhos: daqueles que tem o corpo coberto de fubá aos que ostentam mãos de pilão; dos que andam nus e seduzem mulheres aos moleques invisíveis que assustam o cavaleiro sem nunca se revelar (LOBATO, 2008).

Essa é a potência da oralidade, que permite não apenas o surgimento de tantas versões riquíssimas, mas também sua coexistência e complementariedade. No momento da criação artística, entretanto, é preciso cristalizar a forma. A tergiversação 
fica de fora, as características que melhor servem ao personagem e obra são elencadas e as outras, invariavelmente, acabam sendo deixadas de lado.

Outro marco também contemporâneo ao de Lobato foram os Modernistas, a partir de 1922. É assim que surgirão obras como Macunaíma, de Mário de Andrade (1928), inspirado no mito de etnias do Norte do Amazonas, como Taurepang, Wapichana e outras. Também do Norte veio a inspiração de Cobra Norato, de Raul Bopp (1931). A bússola que orientava os modernistas era o desejo de devoração exposto no Manifesto Antropófago (1928), assinado por Oswald de Andrade: deglutir o estrangeiro e produzir algo fundamentalmente nosso.

O que separaria a deglutição original de um pastiche de ideias puramente estrangeiras? A consciência deste processo apropriativo é um destes diferenciais, mas não apenas isso. O que se buscava com a devoração antropófaga era também inverter polaridades, dar valor a tudo aquilo que antes era devassado pela crítica eurocêntrica. Como no Abaporu, de Tarsila do Amaral (1928), trocamos o império dominante da cabeça que pensa pela crueza afetiva dos pés descalços que, enormes, tocam toda a terra. Passaríamos a valorar não apenas o popular, mas também a preguiça, a malandragem e a simplicidade.

O imaginário que movimentava Thoms contra o cavalo de ferro que a tudo solapava continua operante. Mas neste momento, após o choque de desumanidade que o progressismo moderno nos trouxe, percebemos que a tecnização não era das práticas, mas dos pensamentos. E essa sim, era ameaça das mais cruéis. Macunaíma já intuía isso, verbalizando essa ansiedade do momento. "De toda 
essa embrulhada o pensamento dele sacou bem clarinha uma lua: Os homens é que eram máquinas e as máquinas é que eram homens" (ANDRADE, 1998, p.55).

As tensões homem-máquina, natureza-cultura, ciência-tradição convidam a uma exploração pelas artes destes questionamentos a partir da literatura de ficção científica, que demoraria ainda algumas décadas a se consolidar no Brasil. Apenas em 1955, por exemplo, temos a publicação da primeira revista especializada em fantasia e FC do país, a Fantastic, versão nacional da revista homônima norteamericana que contou com 208 edições entre 1952 e 1980. Em seu número de estreia, a publicação trazida ao Brasil pela Cinelar teve como participação nacional apenas um conto, assinado pelo editor Zaé Junior, e uma charge de Mendoza. De resto, todos autores estrangeiros. Curioso que mesmo com esse apelo ao exterior, os temas folclóricos se mostram inevitáveis. Tanto que justamente os primeiros trabalhos são ambos de inspiração folclórica: o conto tratava do caboclo d'água e a ilustração, por sua vez, era da Cuca (CAUSO, 2003, p.240).

Entre devorações e pastiches dos autores da, assim chamada, Primeira Onda da FC nacional, o manifesto oswaldiano encontra seu eco em um novo documento, proposto por Ivan Carlos Regina em 1988: O Manifesto Antropofágico da Ficção Científica Brasileira. Nele encontramos um reforço das tensões mencionadas, plasmadas em neon e folclore.

Um boitatá de olhos de césio espreita no planalto central do país (...) Uma mula sem cabeça cospe fogo radioativo pelas ventas (...) Um Saci Pererê matuta, com uma prótese de vanádio, 
masca mandioca, tritura paçoca e arrota urânio enriquecido. (...) Um caipora verde amarelo devora hambúrgueres, destrói satélites, deglute armas e destroça tecnologias. (REGINA, 1988)

Claro que aqui temos mais a referência ao texto fonte do que qualquer outra coisa, mas é interessante notar como o jogo do que é devorado e o que é devolvido se mistura. Não mais separado entre o que é "deles" e o que vira "nosso". O Saci androide masca a mandioca, síntese da brasilidade originária - seja enquanto base gastronômica, seja enquanto lenda das mais conhecidas - e devolve urânio enriquecido; a epítome da técnica, causadora de cataclismos. A Mula sem Cabeça queima não mais com o fogo do inferno, mas com radioatividade. Local e o global se misturam na mesma aldeia sob o risco da destruição. E ante o medo da morte o imaginário se movimenta em arte.

\section{TENTATIVAS DE NOMENCLATURA}

Não seria correto buscar reivindicar com este texto uma autoria pela "criação" do termo Ficção Folclórica. O termo já foi usado anteriormente, e o pode ter sido feito há muito por qualquer pessoa que tenha pensado em delimitar narrativas de ficção construídas a partir de uma inspiração no imaginário popular. Mesmo em inglês, o termo Folkloric Fiction já foi utilizado, em 2008, por Jason Marc Harris em seu livro Folklore and the Fantastic in Nineteenth-Century British Fiction ao buscar um sinônimo para as narrativas com as quais estava trabalhando - a saber, aquelas centradas em contos populares do século XIX.

Então quais os motivos de buscar com este artigo dar cidadania acadêmica à Ficção Folclórica? É que, mais uma vez, 
não basta o termo existir, ele precisa ser conceituado. E ao conceituar o que se percebe ser esse movimento contemporâneo de surgimento da Ficção Folclórica enquanto subgênero da ficção especulativa, percebemos a necessidade de distinguilo de outras manifestações literárias anteriores e de tentativas contemporâneas de nomenclatura.

As primeiras aproximações entre ficção e culturas populares, ainda de uma perspectiva romântica, gerou o Regionalismo. Vários são os autores que se debruçaram para compreender quais os limites deste termo, mas ainda cabe a crítica pontual de Lúcia Miguel-Pereira: "se considerarmos regionalista qualquer livro que, intencionalmente ou não, traduza peculiaridades locais, teremos que classificar desse modo a maior parte da nossa ficção" (1988, p.175).

Prosseguindo sua reflexão, a autora sugere algumas peculiaridades para que uma obra possa ser considerada pertencente ao gênero. Seu fim primordial deve ser a fixação de tipos, costumes e linguagens, "cujo conteúdo perderia a significação sem esses elementos exteriores, e que se passem em ambientes onde os hábitos e estilos de vida se diferenciem dos que imprime a civilização niveladora" (PEREIRA, 1988, p.175).

Impossível negligenciar neste momento a crítica tecida por Adriana de Fátima Barbosa Araújo quanto à observação final de Pereira. Quando há a necessidade das histórias se passarem em ambientes distintos daqueles que exprimam os modos de uma civilização que nivela, se assume uma lógica colonizadora que distingue os espaços interioranos e urbanos entre bárbaros e civilizados (2006, p.115). 
Lúcia Pereira divide o Regionalismo no início do século XX em diversos "surtos", que caracteriza cada qual com suas singularidades. A mesma distinção não percebe Antônio Cândido, que a tudo entende, nas primeiras duas décadas dos 1900, como uma literatura satisfeita, com alma de cronista social, consolidando-se na forma do "conto sertanejo", que o crítico descreve assim:

Gênero artificial e pretensioso, criando um sentimento subalterno e fácil de condescendência em relação ao próprio país, a pretexto de amor da terra, ilustra bem a posição dessa fase que procurava, na sua vocação cosmopolita, um meio de encarar com olhos europeus as nossas realidades mais típicas. Esse meio foi o "tonto sertanejo", que tratou o homem rural do ângulo pitoresco, sentimental e jocoso, favorecendo a seu respeito idéias-feitas perigosas tanto do ponto de vista social quanto, sobretudo, estético. (CÂNDIDO, 2006, p.121).

Alfredo Bosi preferirá chamar "Sertanismo" a essa literatura regionalista, em suas várias fases: Da romântica do século XIX à naturalista, acadêmica e modernista. Nessa abordagem, Bosi mostra várias ressalvas quanto a esse tipo de literatura. Para ele haveria duas possibilidades extremas do surgimento de bons trabalhos nessa área: o primeiro seria o escritor trabalhar no puro registro da cultura popular, o que chama de "neofolclore" - como identifica em Simões Lopes Neto; e o segundo que, ao mergulhar na rede referencial da vida rústica do povo, reconstrua-os em novos códigos de comunicação para o leitor culto. Exemplo do último caso percebe na obra de João Guimarães Rosa (BOSI, 1980, p.156). Poucos são, entretanto, aqueles que se saem bem-sucedidos nessa empreitada. 
Como o escritor não pode fazer folclore puro, limita-se a projetar os próprios interesses ou frustrações na sua viagem literária à roda do campo. Do enxerto resulta quase sempre uma prosa híbrida onde não alcançam o ponto de fusão artístico o espelhamento da vida agreste e os modelos ideológicos e estéticos do prosador. (BOSI, 1980, p.155)

Tendo levantado algumas visões principais no campo da literatura sobre o que consistiria uma literatura regionalista e/ ou sertanista, podemos identificar alguns padrões. De Lúcia Pereira capturamos a ideia das finalidades e o colonialismo condescendente. De Cândido, os perigos da estereotipia, do distanciamento do olhar - ainda europeizado - e de um nacionalismo impositivo, embelezador e por vezes acrítico. De Bosi, por sua vez, compreendemos as dificuldades frustradas de unir estética do prosador com as referências folclóricas.

Dessas observações, partimos para uma conceituação peculiar da Ficção Folclórica enquanto um subgênero da ficção especulativa onde os saberes locais, a cultura dos povos originários e principalmente os mitos e lendas do imaginário popular servem de motor para a narrativa literária. Seu fim primordial é a exploração e (re)descoberta deste Brasil profundo habitado por seres encantados, a partir do qual os demais elementos de brasilidade vão emergindo na trama de acordo com cada obra. É na busca pela fantástica popular que o narrador encontra espaço para vozes e sotaques, sabores e pratos típicos, frutas da estação e matas nativas, danças, cantigas, parlendas. Não apenas isso, mas também o próprio país se abre ao escritor, revelando seus personagens históricos ignorados 
pelos grandes livros, seus povos originários marginalizados dos processos democráticos, seus modos e costumes soterrados pela hegemonia do Sudeste.

Os cenários também não se restringem apenas aos campos e fazendas, mas se espalham das cidades até os confins do espaço sideral. Não apenas a Fantasia clássica torna-se meio para explorar essas histórias, mas também o terror e a ficção científica. O próprio Câmara Cascudo já dizia que mesmo o transatlântico, o avião atômico e o laboratório químico podem ser objetos de interesse folclórico na medida em que inspirem, no plano popular, hábitos, costumes, gestos, superstições, indumentárias, sátiras, assimiladas por grupos sociais participantes. Por que o folclore não está ligado aos meios ou aos espaços, mas ao ser humano. "Onde estiver um homem aí viverá uma fonte de criação e divulgação folclórica" (CASCUDO, 2002, p.240).

É por isso que se torna tão limitante, ao pensar em tentativas de nomenclatura para as obras deste escopo, tentar enquadrálas em uma Fantasia Rural, como se em oposição a uma Fantasia Urbana. Espaços não são importantes, mas sim as práticas e as relações. A Ficção Folclórica vem mostrar que a cultura popular não vive distante de nós, seja em questão de espaço seja em questão de tempo - como algo restrito à criança ou ao idoso. Folclore não está lá, mas aqui. Conforme as narrativas vão sendo exploradas e novos nichos descobertos, os olhos só tendem a se abrir cada vez mais.

Igualmente insuficiente para o gênero como um todo seria adotar a classificação pela qual a escritora Simone Saueressig identifica suas obras: "fantasia de registro folclórico" - aquela escrita a partir de relatos da cultura popular. Primeiro, é claro, pela 
restrição nominal ao gênero da Fantasia. Em segundo, por parecer denotar, ainda que sem ser sua intenção, muito daquilo que Alfredo Bosi criticava ao se referir ao sertanismo (1980): um neofolclore mais no âmbito da coleta (o registro) e menos no da criação. É algo identificável no próprio capítulo dedicado à literatura de inspiração folclórica no livro O Fantástico Brasileiro, de Matangrano e Tavares (2018, p.209). Nele ao lado de ficcionistas, encontramos menções aos textos de Câmara Cascudo, Gilberto Freyre, Franklin Cascaes e outros folcloristas que apenas deram forma escrita a contos recolhidos em suas comunidades interpretativas.

Cabe menção também o termo "Borduna \& Feitiçaria" usado por Roberto de Sousa Causo para descrever seu livro A Sombra dos Homens (2004), uma fantasia heroica indigenista que se passa em um Brasil anterior ao descobrimento. A referência é clara ao gênero Espada \& Feitiçaria, de autores como Robert E. Howard, de Conan (1932). É uma sugestão curiosa, mas bastante singular e, mesmo hoje em dia, seria capaz de englobar apenas um número limitado de histórias além dela própria.

\section{FICÇÃO FOLCLÓRICA}

\section{Primeiros anos}

Identificamos um paralelo entre o estabelecer da Ficção Folclórica brasileira e a formação do movimento Fantasista, ainda que, como perceberemos ao longo deste histórico, esta primeira ainda esteja em um patamar muito inicial frente a todo o restante da corrente.

Tavares e Matangrano (2018, p.265), ao sugerirem o Fantasismo enquanto movimento literário que emerge no Brasil à partir da 
virada do século XXI, consolidando-se após sua primeira década, apontam como um dos marcos para este processo o sucesso comercial de um livro de fantasia escrito por um brasileiro e com cenários igualmente tupiniquins: Os Sete, de André Vianco (2000). A saga dos vampiros lusitanos libertos de sua prisão de prata em um Brasil contemporâneo mostrou para o mercado que uma obra assim poderia ser bem-sucedida.

Mais uma vez, é difícil resumir os motivos para o sucesso: o terror aventuresco, sombrio na medida certa para atrair o público jovem; a estética que bebia muito das audiovisualidades - especialmente Matrix - e os superpoderes vampíricos, que lembravam muito as histórias em quadrinhos certamente contribuíram. Mas um dos grandes chamarizes da obra foi a possibilidade do público ver retratado os espaços conhecidos e familiares em uma narrativa fantástica. O reconhecimento era imediato. Havia um Brasil que queria ser visto e (re)encantado.

Vianco abraçou a bandeira da brasilidade neste início de carreira. Tanto que na conclusão de sua próxima grande saga, $O$ Vampiro Rei Vol. 2 (2005) incorporou mitos folclóricos como adversários de seus protagonistas. Na história, uma bruxa indígena - cansada dos males causados pelos brancos ao seu povo -, invocou uma magia proibida, trazendo a Noite Maldita e, com ela, os vampiros. Dois espíritos protetores são invocados pela bruxa para lutar contra os heróis: um saci, ainda que não seja assim identificado, e um boitatá6 . Reconhecemos o saci por conta de nossa própria intertextualidade,

6 Antes de Vianco cabe mencionar, outra obra brasileira também abordou vampiros e fez referência ao folclore. Trata-se de O Vampiro que Descobriu o Brasil (1999) de Ivan Jaff. Nela, a Mula Sem Cabeça acaba sendo um animal mordido que, incapaz de morrer, mesmo com a cabeça decepada permanece viva. 
na descrição do duende negro, "malino" e que se locomove em redemoinho. Anos depois no spin-off de sua série principal, $O$ Turno da Noite: O Livro de Jó (2007), Vianco revela que os poderosos guardiões mencionados desde o primeiro livro são nada mais, nada menos, do que curupiras.

Algo parecido faz outro autor que representa também um marco no movimento fantástico contemporâneo estabelecido por Matangrano e Tavares (2018, p.265). Trata-se de Eduardo Spohr, que lança em 2007 a primeira edição de A Batalha do Apocalipse colocando o Rio de Janeiro como cenário de uma guerra entre anjos e demônios. No spin-off da série, lançado em 2011, Filhos do Éden: Herdeiros de Atlântida, quando já passa a integrar o selo Verus da editora Record, Spohr incorpora o folclore nacional ao seu universo. O curupira que enfrenta os protagonistas, do mesmo modo que o Saci na obra de Vianco, não é em momento algum nomeado, mas o leitor que compartilha o fundo comum da cultura popular brasileira o reconhece graças aos seus indefectiveis pés voltados ao contrário.

Se é possível traçar um paralelo entre estes dois acontecimentos, pontuamos: após terem contado a primeira história que os consagrou e buscarem novas narrativas nas quais se inspirarem, é a fantástico brasileiro, na forma de suas pulsões folclóricas, que vai emergir como uma fonte de inspiração latente incapaz de ser ignorada.

Por que, em certos casos, os autores preferiram não chamar os mitos pelos seus nomes? Duas possibilidades podem ser levantadas, ambas complementares. A primeira, para fugir da obviedade, confiando que a rede de referências permita ao leitor a identificação sem a necessidade do narrador o explicitar. A segunda, para escapar 
de possíveis rejeições por parte de leitores que, tal qual os críticos de testa enrugada e olhar inspirado do século XIX, julguem mitos e lendas do folclore brasileiro uma tolice popular, incompativel com o que se propõe a consumir.

Ainda assim, a mera presença coadjuvante destes mitos em obras do cânone do Fantasismo brasileiro não é suficiente para representar um marco inicial na ficção folclórica. Antes, estes exemplos apenas a circundam e, de certa forma, a possibilitam. Bento continua sendo uma história de vampiros, assim como Filhos do Éden é uma história de anjos.

Evidentemente é certo que pode ter havido uma infinidade de produções de baixa tiragem e pouco alcance, com circulação hiperlocal, mas cuja repercussão foi insuficiente para marcar o gênero. Se podemos pensar em um marco - a partir da publicação de uma obra mais consistente em uma editora consolidada -, mesmo que sem a mesma expressão mercadológica dos best-sellers nacionais da época, podemos elencar a publicação da novela de Roberto de Sousa Causo A Sombra dos Homens (2004) pela Devir?. Nela, por fim, temos uma história guiada por mitos, e seus desdobramentos são consequência do desejo de explorar esse Brasil profundo.

A saga de Tajarê, narrada neste livro, é um marco tanto pelo período em que foi lançada quanto por seus desdobramentos subsequentes. Foi em busca de um espaço para lançar a continuação da novela que Causo encontrou, na Fantasticon 2010 (IV Simpósio de Literatura Fantástica), o escritor Christopher Kastensmidt e estabeleceu com ele a parceria que daria origem primeiro aos três 
livros de bolso Dupla Fantasia Heróica (2010, 2011, 2012) e, em seguida, à versão em português do romance de ficção folclórica $A$ Bandeira do Elefante e da Arara (2016) - que tem Causo como seu tradutor -, uma vez que Kastensmidt escreve diretamente em inglês.

Ainda na primeira década do novo milênio, como parte da consolidação do movimento de escritores de ficção especulativa no Brasil, surgem diversos zines independentes que vão, vez ou outra, abrir espaços direcionados em suas chamadas para o folclore brasileiro. Em 2007, Giulia Moon, autora que estava se destacando no cenário a partir do sucesso das histórias de vampiro foi a editora convidada do vol. 18 da revista Scarium ${ }^{8}$, que trouxe a Loira do Banheiro como capa. O próprio título da publicação ditava o tom das histórias, sempre voltadas para o terror, evocando em suas páginas do horror corporal da lenda urbana do bebê diabo até o gore imagético de corpos destroçados por crocodilos de uma versão reimaginada da Cuca.

Anhangá - A Fúria do Demônio de J. Modesto (2008) será publicado pela Giz, a mesma casa editorial que pouco depois receberá Walter Tierno para a publicação de Cira e o Velho (2010). Narrado em dois tempos distintos, o livro acompanha de um lado o embate entre o bandeirante Domingos Jorge Velho, personagem histórico responsável pela destruição do Quilombo dos Palmares, e Cira, a bruxa indígena filha de Cobra Norato. Do outro, temos um narrador obcecado por encontrar Cira no tempo presente, redescobrindo mitos antigos em vícios contemporâneos, em uma inspiração declarada da obra de Neil Gaiman. Mais uma vez, temos um curupira não nomeado.

8 Ver http://www.scarium.com.br/dezoito.html. Acesso em 20.Jun.2018. 
O Guardião da floresta, por exemplo: ele ainda tem os cabelos vermelhos, mas deixaram de ser desgrenhados e sujos. Hoje em dia, ele usa um gel muito cheiroso e os mantém cortados e limpos. Sua pele não é mais verde e seus pés não estão mais virados para trás. (...) Ele trocou as árvores e o céu limpo por boates mal iluminadas com cheiro de água sanitária. Não cuida mais de bichos, mas de prostitutas. E está ganhando muito dinheiro com isso (TIERNO, 2010, p.139).

\section{Expoentes do mercado}

É finalmente a partir de 2010 que a Ficção Folclórica brasileira começa a se constituir como um subgênero próprio, marcado pelo maior foco de suas obras. Podemos considerar que existem dois grandes expoentes neste campo, que atingiram tanto o sucesso mercadológico quanto a consolidação profissional de seus serviços editoriais. O primeiro é Christopher Kastensmidt, com a já mencionada série $A$ Bandeira do Elefante e da Arara, publicada em romance pela Devir em 2016, e o outro é Felipe Castilho com a, até então trilogia, O Legado Folclórico lançado pela Gutemberg (2012, 2013, 2015).

A série de Kastensmidt tem uma trajetória bastante única. Sua estreia ocorre na revista norte-americana Realms of Fantasy, com o título The fortuitous meeting of Gerard van Oost and Oludara. Graças à esta exposição, chegou a concorrer como finalista do Prêmio Nebula, um dos mais importantes para os escritores de ficção especulativa.

No Brasil, a série foi lançada inicialmente nos Duplos de Fantasia Heróica da Devir, em narrativas episódicas que podiam ser lidas de 
maneira isolada, e que depois se tornaram os três primeiros capítulos do romance lançado em 2016. Ainda seguindo a estrutura episódica, Kastensmidt lançou de maneira independente e em inglês alguns dos capítulos na forma de oito livros vendidos separadamente pelo Kindle Direct Publishing. A estratégia deu certo, e, também, em 2016, a Bandeira teve seus direitos vendidos para a China pela editora Douban Read, e na Espanha, em 2017, pela editora Sportula.

Outra estratégia editorial inovadora para tornar a obra acessível para os grandes mercados foi realizada logo antes de seu lançamento. Em uma parceria da Devir com a Mistery Box Nerdloot, que a cada mês distribui uma caixa com produtos sortidos da cultura geek e nerd para seus assinantes, mais de 5 mil pessoas receberam uma edição em pré-venda do romance da Bandeira, fazendo esse se tornar um best-seller imediato para os padrões brasileiros.

Christopher Kastensmidt é texano radicado no Brasil desde os anos 2000. A Bandeira concentra muito dessa curiosidade do estrangeiro para com o exotismo do país - e aí está um dos motivos de seu sucesso no exterior. No início da aventura, seus personagens, o bandeirante holandês Gerard Van Oost e o negro liberto Oludara, se maravilham com tudo que se deparam nas matas, inclusive com as coisas mais banais. É seu encontro com o Saci Pererê que Ihes servirá de guia neste Brasil encantado que o leitor também vai descobrir. No entanto há mais do que isso no livro. Há uma preocupação na obra com a estereotipia colonizadora, que poderia facilmente ser reforçada haja vista a biografia do próprio autor. Negros e indígenas têm voz e ação, e mulheres também encontram seu espaço de agência. Mesma preocupação inclusiva foi levada para o RPG da Bandeira, lançado em 2017. 
É importante frisar este ponto, especialmente tendo em vista o histórico de obras que revisitam o período colonial brasileiro. Nos anos 1990 não tivemos grande produção literária ligando fantasia e folclore, mas no universo dos RPGs, não se pode esquecer dos diversos suplementos da série Desafio dos Bandeirantes (1992) de Carlos Klimick, Luiz Eduardo Ricon e Flávio Andrade. Marcadamente um primeiro convite para que o brasileiro pudesse revisitar um Brasil pretérito, habitado por criaturas folclóricas, o jogo pecava por expor de início uma visão demonizadora dos mitos indígenas, e por apresentar - em um desejo de precisão histórica -, manifestações de racismo e exclusão que a ficção e o gameplay podem justamente ajudar a superar. Algo que mais tarde os criadores buscaram fazer em suplementos dedicados exclusivamente ao universo quilombola.

Já Felipe Castilho viu o primeiro volume de seu livro da série O Legado Folclórico, intitulado Ouro, Fogo e Megabytes publicado pela Gutemberg em 2012. Desta vez, deixa-se de lado o período colonial para retornar à contemporaneidade, em uma história que faz o folclore brasileiro se encontrar com o universo dos MMORPGs, com o dia a dia de um aluno de ensino regular e com os calçadões de São Paulo.

A série acompanha a história do garoto Anderson Coelho, então com 12 anos de idade, que é abordado enquanto jogava on-line por uma pessoa que, mais tarde, revela-se um "meio-caipora". Este personagem o introduzirá no mundo da Organização, um grupo composto por seres encantados vivendo sob os cuidados do Patrão - um saci nada bemhumorado - que busca impedir os planos de um grande empresário de usar os mitos folclóricos para sua própria fortuna. 
O uso dos personagens híbridos, como meio-caiporas, meio-curupiras, filhas de iaras, ajuda a transmitir essa ideia de que não haverá pureza de registro. O folclórico em seu estilo mais clássico pertence ao passado, mas hoje carregamos seu legado, seja na herança de nossa ascendência, seja nos diálogos que estabelecemos para que o tradicional se mantenha vivo e significativo na vida das pessoas.

O primeiro volume é adotado por escolas e ganha um público que se consolida com o lançamento dos demais volumes, Prata, Terra e Lua Cheia (2013) e Ferro, Água e Escuridão (2015). Ao longo dos livros não apenas o protagonista vai crescendo - e assim também seus problemas - como o escopo do livro também aumenta. Assim, se de início o cenário centrava-se em uma dualidade zona rural zona urbana e na familiaridade hegemônica do Sudeste, nos demais os personagens viajam pelo Brasil inteiro, das águas do Guaíba no Rio Grande do Sul ao São Francisco no Nordeste, onde se passa boa parte da trama do terceiro livro. Em cada nova região, novos mitos se revelam - marcos que são da gente e dos espaços que representam. Inclusão aqui é uma pauta ainda mais marcante. $\mathrm{O}$ protagonista é negro, um dos personagens mais queridos pelos leitores, se revela homossexual e há constantes mensagens de enfrentamento ao capitalismo predatório.

O sucesso editorial de Castilho com O Legado Folclórico é um dos motivos que o levam a estabelecer uma parceria inédita na literatura brasileira. Em sua nova obra, A Ordem Vermelha: Filhos da Degradação (2017), o autor assinou contrato não com uma editora, mas com um evento, a Comic Con Experience (CCXP). Foi apenas em um segundo momento que a editora Intrínseca se envolveu no 
processo, fazendo o livro ser lançado com uma tiragem inicial de 30 mil exemplares.

\section{Produções independentes e pequenas editoras}

Achegada dos anos 2010 trouxe consigotambém o barateamento do maquinário de produção e dos custos gráficos, novas pequenas editoras dispostas a investir no mercado e o surgimento de iniciativas de autopublicação convidando os escritores a dar vazão às histórias que sempre quiseram ver publicadas. Muitas delas com inspiração nas culturas populares.

Foi o caso de Simone Saueressig. Apesar de seus 30 anos de produção literária na área da ficção especulativa, a autora optou pela autopublicação para fazer circular as narrativas que as editoras não se dispunham a distribuir. Foi o que fez em 2012 com Contos do Sul, uma coletânea de histórias curtas de terror inspiradas diretamente em Lendas do Sul de Simões Lopes Neto - obra que completaria um século no ano seguinte. Mais tarde, fez o mesmo com a série que ainda hoje considera sua maior obra: a quadrilogia Os Sóis da América (o primeiro de 2013, os demais de 2014).

Nela, o contador de histórias de um povo do sul da América morre. Como era a força de sua oralidade que marcava a transição temporal que trazia o fim da noite e o raiar do dia, desde que o ancião partiu o Sol deixou de nascer. Pelume, o protagonista, parte então por uma jornada que o leva por todo o continente americano até onde ele possa encontrar o Sol para levá-lo de volta ao seu povo. No caminho, encontra diversas criaturas mitológicas não apenas do Brasil, mas da América Latina e da Central. Com isso, percebemos também que ao se falar em Ficção Folclórica não a limitamos a uma 
defesa nacionalista de brasilidade. Afinal, as trocas culturais sempre se dão em territorialidades que expandem e muito as fronteiras das linhas geopolíticas.

Iniciativas independentes buscariam organizar estes autores que já estavam se consolidando na Ficção Folclórica com novos e antigos talentos prontos para darem vazão às narrativas inspiradas pela poética popular. Em 2013 surgem no mercado duas antologias de contos exclusivamente dedicadas ao lendário nacional: a Brasil Fantástico - Lendas de um país sobrenatural da Draco e Quando o Saci Encontra os Mestres do Terror da Estronho, 2013. A primeira abre justamente com um conto de Christopher Kastensmidt enquanto a segunda escolhe um conto de Walter Tierno para a abertura. São já, em tão pouco tempo, os nomes de destaque da Ficção Folclórica nacional.

Coletâneas e antologias se mostrariam ao longo dos anos um grande espaço para que autores se arriscassem em projetos solo ou coletivos de revisita aos mitos e lendas tradicionais. Destacamos, por exemplo, Lauro Kociuba com a coletânea de ficção folclórica Raízes de Vento e Sangue (2017), que concorreu ao prêmio Le Blanc $^{9}$ como melhor antologia de Fantasia, Ficção Científica e Terror. O livro vencedor da categoria foi a Antologia Mitografias Mitos Modernos (2017), organizada por Andriolli Costa, Leonardo Tremeschin e Lucas Rafael Ferraz, que contém vários de seus contos dedicados ao folclore brasileiro desde os mais detetivescos aos com estética cyberpunk. Mais recentemente foi lançada ainda a antologia Cantigas no Escuro, organizada por Laura Pohl (2018),

9 I Prêmio Le Blanc de Arte Sequencial, Animação e Literatura Fantástica, organizado pela UFRJ e Universidade Veiga de Almeida. 
apenas com escritoras mulheres que buscaram nas cantigas infantis inspiração para suas histórias de terror.

Percebemos neste momento um surgimento cada vez maior de autores e criadores de conteúdo, mesmo em outras áreas, interessados em explorar este Brasil tão pouco conhecido pela ficção contemporânea. Ainda assim, são iniciativas distintas que pouco se conversavam e se perdiam no imenso fluxo de informações das redes socais. Portanto, seria impossível falar de uma consolidação da Ficção Folclórica brasileira sem perpassar pelo surgimento do grupo "Vozes Ancestrais".

O grupo teve sua origem em 2015 a partir de um diálogo inicial entre a escritora Francélia Pereira e o autor Vilson Gonçalves. Ela havia acabado de lançar o romance de ficção científica Habitantes do Cosmo (2014) em autopublicação pelo Clube de Autores, levando a lenda das icamiabas para um novo planeta. Ele, da mesma maneira, havia acabado de publicar, pela Buriti, o livro A Canção de Quatrocantos (2014).

Era prática comum entre os grupos de escritores no Facebook organizar eventos exclusivamente virtuais onde uma programação de autores, cada um respeitando seu respectivo horário combinado, faziam postagens sobre seus livros, respondiam perguntas, interagiam com o público e sorteavam brindes. Ao perceberem que a estratégia era corriqueira entre escritores de Fantasia clássica ou Hot, surgiu entre Pereira e Gonçalves o desejo de construir algo semelhante, reunindo produtores de conteúdo que trabalhavam com folclore, culturas originárias ou povos ameríndios em interface com a cultura pop. 
A primeira edição foi feita em janeiro de 2016 e foi seguida por outras três naquele mesmo ano que consolidaram muitos diálogos ainda em andamento. Entre os escritores além dos dois fundadores, passaram pelo evento R. B. Montenegro com o livro As Crônicas de Pindorama - Piná e o despertar da escuridão (2015), Jan Santos, com A Rainha de Maio (2016) e Felipe Castilho no auge do lançamento do terceiro livro do Legado Folclórico.

Seria equivocado, entretanto, restringir esse movimento à literatura. O desejo de narrar essas histórias se expande em várias mídias, chegando às HQs, à música, aos videogames. Integraram as edições do Vozes Ancestrais representantes dos games Batalha de Mitos (Alpha Centauri), Guerreiros Folclóricos (Unique) e Kerana (Smart Studio), nenhum dos quais foi lançado até hoje. Participaram também o cineasta Sander Silva, criador da websérie Caçada nas Horas Mortas; o jornalista Andriolli Costa apresentando os projetos de divulgação folclórica do Colecionador de Sacis; os quadrinistas Giorgio Galli de Salomão Ventura - Caçador de Lendas e Hugo Canuto - que então desenvolvia o projeto A Canção dos Mayrube, com inspiração na mitologia Guarani, e que logo depois ganharia notoriedade com Contos dos Orixás.

Leo D. Andrade, criador do mangá com A Lenda de Boia (2017) apresentou no evento, e foi nele que conheceu a escritora Vania P. S. Hu'yju, autora de Jegwaká - O Clã do Centro da Terra (2016) -, que trabalha com indígenas no Mato Grosso do Sul. A partir desse contato, conseguiu lançar uma versão de sua obra também em Guarani ${ }^{10}$. Outra parceria estabelecida foi entre as ilustradoras

10 Ver https://issuu.com/alendadeboia/docs/um_dia_de_ca__a._vers__o_guarani_k. Acesso em 20.Jun.2018. 
Natália e Bianca Duarte, da página Brasil Folclórico, que se apresentaram em várias edições do evento, e acabaram por ilustrar o álbum Wdê Nnãkrda da banda de metal Arandu Arakuáa, que busca na cultura e mitologia indígena inspiração para suas letras. Ambos se conheceram também nesses eventos.

Após 2016 não houve novos eventos, mas um grupo de Facebook permaneceu de certa maneira ativo, congregando interesses. Francélia Pereira após a publicação inicial pelo Clube de Autores publicou a versão física de Habitantes do Cosmos pela Editora Multifoco. A mesma que publicaria em 2017, o livro Marani de Alan de Sá, uma ficção folclórica colonial que acompanha a história de uma filha do boto, a personagem título, que parte em uma jornada para encontrar seu irmão gêmeo perdido e acaba se envolvendo em disputas ideológicas entre os dois seres mais poderosos da floresta: lara e Caipora. O escritor, que vive em Feira de Santana/BA, publicou os primeiros capítulos do livro na plataforma digital Wattpad. Com a resposta do público e o compromisso de terminar o original, conseguiu o contrato com a editora e uma publicação tradicional.

Identificamos desde o início um grande investimento em histórias de fantasia heroica e no terror, apostando fortemente num desejo de renegar à imagem residual que vincula folclore à literatura infantil deixada pela obra lobatiana. Isso ainda hoje se percebe, haja vista a resenha publicada pela revista Rolling Stone do livro O Escravo de Capela de Marco DeBrito, que reimagina uma origem sombria para o saci: "Esqueça Monteiro Lobato" (GUIA DE LIVROS, 2017). 
Por outro, tínhamos um mercado que propositalmente vinha sendo negligenciado. Gustavo Rosseb, com sua série A Odisseia de Tibor Lobato, assume de vez a referência ao Sítio do Picapau Amarelo e constrói uma história de ficção folclórica voltada para um público infantil que se inicia em 2012, pela editora Patuá. Os dois últimos volumes, lançados em 2016 e 2017, já são publicados com os direitos da série vendidos para o cinema. Essa tendência vem se tornando mais comum recentemente. Em 2013, é publicado Deuses de Dois Mundos - o Livro do Silêncio, de PJ Pereira, o primeiro de uma trilogia inspirada nas religiões e na cultura popular afrobrasileira. A informação de que os direitos já foram vendidos para o cinema é usado inclusive na quarta-capa dos livros, de modo a impulsionar ainda mais as vendas.

Outra tendência percebida é a busca por métodos alternativos de publicação da obra, especialmente via financiamento coletivo. No caso das obras de ficção folclórica, o mercado das histórias em quadrinhos já descobriu isso há muito, publicando em profusão obras de Ikarow, Hugo Canuto, Caroline Calzolari, Roberta Cirne e Rodrigo Otäguro. No campo da literatura, o folclore começou a ser explorado com uma campanha longamente planejada por lan Fraser com seu Araruama O Livro das Sementes (2017) ${ }^{11}$, financiado com quase $\mathrm{R} \$ 37$ mil, sendo o livro de fantasia mais bem-sucedido da plataforma Catarse. Fraser investiu em artes para divulgação nas redes sociais, contratou espaço em canais do YouTube especializados na recomendação de livros (os booktubers) e fez a campanha virar. Atualmente prepara o lançamento do segundo volume, O Livro das Raízes ${ }^{12}$ (2018), também financiado pelo Catarse com quase $\mathrm{R} \$ 63 \mathrm{mil}$. 


\section{CONSIDERAÇÕES FINAIS}

Investimos bastante espaço para dar este panorama da ficção folclórica brasileira sabendo que, por mais extenso que este artigo se tornasse, ele ainda seria incompleto. Primeiramente, por ser impossível conhecer e mencionar toda a produção ficcional que buscou construir interfaces com as culturas populares. Em segundo, por ser esta uma área em constante expansão, na qual obras novas são descobertas todos os dias com uma base de leitores consolidada, mas ainda invisíveis para as grandes editoras. Sabendo dessa insuficiência, que as lacunas deixadas por este trabalho tão inicial sirvam como convite para que outros pesquisadores possam preenchê-las no futuro.

O que falta para que o folclore brasileiro atinja os mercados de massa? Notícias recentes dão conta de que um pitch ${ }^{13}$ envolvendo uma história de terror com sacis foi comprado por uma produtora do Reino Unido ${ }^{14}$. Outras, de que o diretor Carlos Saldanha se uniu à Netflix para produzir uma série detetivesca inspirada no folclore nacional ${ }^{15}$. Precisaremos do audiovisual para guiar as rédeas editorias? Ou será este o começo de um processo que levará à estafa produtiva da ficção folclórica? O tempo dirá.

Antes de chegarmos a isso temos problemas mais urgentes e diretos para investigar. De começo, o Wattpad e as pequenas editoras se tornam um grande espaço para o surgimento de novos autores e narrativas. No entanto, também é preciso ter um ponto de vista crítico. Nem toda editora desse porte tem

13 Apresentação direta e curta, com o objetivo de vender a ideia de um projeto.

14 Ver https://deadline.com/2018/06/hindsight-media-horror-pitch-saci-brazilianchristmas-prince-nate-atkins-netflix-1202401777/. Acesso em 20.Jun.2018.

15 Ver https://exame.abril.com.br/estilo-de-vida/netflix-anuncia-nova-serie-brasileiradirigida-por-carlos-saldanha/ . Acesso em 20.Jun.2018. 
cumprido de modo adequado seu papel de revisão, leitura crítica e preparação de originais. Minimamente faz qualquer tipo de triagem do material selecionado, tendo como único critério para publicação a disponibilidade do autor em pagar os custos da gráfica ou de adquirir seu próprio material a preço de custo. O resultado disso é um produto editorial que em nada se distinguiria de uma autopublicação gráfica, com a diferença de que, no caso da autopublicação, o autor assim escolhe e não é obrigado a fazê-lo pela negligência de serviços contratados.

Do ponto de vista da qualidade da produção, também há de se estar atento. Isto porque o autor independente, ao não possuir o segundo olhar de um crivo editorial conta apenas com o próprio bom-senso - ou, no máximo, do apoio dos leitores -, para navegar por este terreno pouco explorado, podendo por vezes incidir em problemas básicos de estereotipia, racismo, reforço colonizador. $\mathrm{E}$ isso se torna bastante pungente na Ficção Folclórica que não apenas vai dialogar diretamente com questões identitárias e, portanto, a nível dos afetos, mas também com sensibilidades culturais que o escritor guiado de início apenas pelo desejo de revisitar a fantástica popular não se via pronto para lidar. Temas como a escravidão, o amaldiçoamento e castigo da mulher, a demonização dos mitos indígena - como o caso do Jurupari e do Anhangá -, fazem parte dos registros folclóricos e aquele que não se dispor a refletir minimamente sobre a superficialidade das fontes consultadas para construir suas narrativas pode acabar meramente reforçando preconceitos e lugares comuns.

Uma destas manifestações estereotípicas que vem de resquício ainda dos textos regionalistas do século XIX e XX. Trata-se da 
distinção pela fala. Ao invés de incorporar a voz narrativa da poética popular como um todo, o autor a restringe a um grupo específico de personagens. Enquanto todos os demais se comunicam normalmente, em colocações pronominais bem colocadas como só a ficção é capaz de construir, alguns personagens tem sua fala marcada pela oralidade - por vezes, inclusive, destacadas do texto com aspas ou itálico -, Eu vô cumê, eu vô fazê, e suas variantes, exemplificamos. Ocorre o seguinte: ainda que ninguém pronuncie corretamente todas as sílabas das palavras no infinitivo da língua portuguesa, independente da classe social ou da educação formal, essa é uma distinção que nós restringimos aos pobres na literatura. Uma distinção absolutamente classista.

Importante trazer essa discussão num texto sobre folclore, pois o próprio Câmara Cascudo relata que por diversas vezes ouviu seus informantes contarem histórias nas quais diziam "prinspo" e "prinspa", mas ainda assim escreveu príncipe e princesa (2004, p.16). As cores e as imagens evocadas pela poética popular não vão estar na grafia, mas na sonoridade da prosódia que o narrador consegue capturar.

Folclore não é peça de museu. Ao escrever sobre ele, escrevemos sobre algo que manifesta a identidade de um povo. Dependendo do trabalho, o autor pode estar lidando com culturas que por muito tempo foram tidas como "subalternas", e a ficção folclórica é a oportunidade de mostrar a riqueza dessa diversidade. Para fazer isso, é importante ir além do senso comum. É se permitir estar afeto a este Outro da cultura popular, e se reconhecer a partir dele. 
Cascudo descreve as histórias folclóricas que ouvia quando criança como o primeiro leite materno de sua literatura (1984, p.16). Essa imagem poética não é apenas rica de beleza, mas de significados. Era o folclore que o nutria de sentidos, de sonhos que ele perseguiria com seus textos. Era o folclore que o confortava, qual mãe que amamenta e afaga. É por isso que uma das dimensões mais importantes daquele que se propõe a escrever sobre o folclore está, repetimos, na afetividade.

Nem todos tiveram a oportunidade de se nutrir de histórias a partir de pais ou avós contadores. Como então seria possível construir essa relação? Como tratar o objeto folclórico com o "devido carinho", nos termos de Osvaldo Orico (1975, p.48)? Sabemos ser possível produzir e compilar relatos sobre seres fantásticos carregados de preconceitos e mesmo negligência, menosprezando as crenças populares, ignorando sua potência simbólica. O afeto é o que permite esta outra relação e ele pode ser construído por meio da pesquisa, do ato presencial e da comunhão - jamais da rejeição.

Investir neste subgênero pode ser uma ótima oportunidade para buscar visitar aldeias, quilombos, assentamentos, comunidades. Visitar outras regiões ou mesmo lugares de sua própria cidade que você nunca antes havia estado. Para conversar com os mais velhos da sua rua ou da sua família. Para revisitar memórias, um patrimônio imaterial em vias de se perder em definitivo pela ação inexorável do tempo. Não para fazer "neofolclore", como acusava Bosi, mas para encontrar inspirações que a mera leitura seria incapaz de oferecer. Se um livro precisa dizer que um mito existe, mas ele não está presente na vida do povo, talvez, como sugere 
Rossini Tavares, o mito já faça parte da história e não mais dessa vivência que se retrata (2003).

A pesquisa de superfície é um problema especialmente em um contexto no qual mesmo com cada vez mais estudos sérios a disposição, as fontes mais acessíveis possuem uma baixíssima confiabilidade, replicando informações erradas ou confusas que acabam encontrando espaço na própria ficção folclórica. No livro Contos Fantásticos do Folclore Brasileiro, de Junior Salvador (2018), por exemplo, encontramos um Boto cor de rosa que em sua forma humana usa chapéu para disfarçar seu enorme nariz de golfinho. Isso é uma má interpretação de sites que espalharam a informação de que o Boto homem não consegue ocultar seu "respirador", ou seja, o espiráculo que todo cetáceo traz no todo da cabeça. Um exemplo entre muitos da necessidade de pesquisa séria para não replicar bobagens.

Com o passar do tempo e a discussão de novos casos exemplares, certamente surgirão dúvidas quanto a classificação aqui proposta. Por exemplo, podem ser consideradas obras de Ficção Folclórica aquelas que narrem histórias de orixás ou deuses indígenas? Tudo depende do contexto. Xangô e Tupã, por si só, são mitos que pertencem às religiões de seus respectivos povos da mesma forma que Jesus pertence ao complexo religioso cristão. Entretanto, mesmo as religiões estão em constantes diálogos com a cultura popular, e é preciso verificar caso a caso essas interfaces. Em Um Outro Pastoreio, de Rodrigo Dmart (2010), é a influência direta dos orixás que faz surgir a lenda do Negrinho do Pastoreio. Da mesma maneira ninguém diria que o próprio conto O Negrinho do Pastoreio, de Simões Lopes Neto (1913), não é um 
de inspiração folclórica mesmo contendo a intercessão divina de Nossa Senhora Aparecida.

Também já existem e existirão casos de escritores de Ficção Folclórica que não irão se identificar com essa classificação, muito por conta do preconceito com o termo folclórico já abordado na seção correspondente. Por certo que é direito deles, e poderão nomear suas obras da maneira como bem entenderem. Cabe ainda o questionamento: após tudo o que expomos neste artigo, a recusa procede? Folclore, ressaltamos, é cultura viva. São modos de sentir, pensar e agir guiados pela tradição. E ele está presente tanto para grupos rurais quanto urbanos, ricos e pobres, quilombolas ou indígenas. Folclore, em última instância, não diz sobre monstros encantados, mas de nós mesmos enquanto seres humanos. $\mathrm{E}$ essa proximidade ancestral nos une enquanto tanta coisa nos separa.

\section{REFERÊNCIAS}

ANDRADE, Mário (1998). Macunaíma - o héroi sem nenhum caráter. Lisboa: Edições Antígona.

ANDRADE, Oswald (1976). "Manifesto Antropófago". In: TELES, Gilberto Mendonça. Vanguarda européia e modernismo brasileiro. Petrópolis: Vozes. ARAÚjo, Adriana de Fátima Barbosa (2006). "O Regionalismo como Outro". Estudos de Literatura Brasileira Contemporânea. (28), 113-124

BATALHA, Maria Cristina (2013). "A literatura fantástica no Brasil: Alguns marcos referenciais". In: RAMOS, Maria Celeste Tomasello; ALVES, Maria Cláudia Rodrigues; HATTNHER, Álvaro Luiz (Orgs.). Pelas veredas do fantástico, do mítico e do maravilhoso. São Paulo: Cultura Acadêmica.

BOSI, Alfredo (1980). História concisa da literatura brasileira. São Paulo: Cultrix. CABRAL, Alfredo do Vale (1978). Achegas ao estudo do folclore brasileiro. Rio de Janeiro: MEC-DAC-FUNARTE - Campanha de defesa do Folclore Brasileiro. 
CÂNDIDO, Antônio (2006). Literatura e Sociedade. Rio de Janeiro: Ouro sobre Azul.

CÂMARA CASCUDO, Luis da (2004). Contos tradicionais do Brasil. Rio de Janeiro: Global.

(2002). Dicionário do Folclore Brasileiro. Rio de Janeiro: Global.

(1984). Literatura Oral no Brasil. São Paulo: EdUSP.

(1967) Folclore do Brasil (pesquisas e notas). Rio de Janeiro: Fundo de

Cultura.

CAUSO, Roberto de Sousa (2003). Fiç̧ão Científica, Fantasia e Horror no Brasil 1875 a 1950. Belo Horizonte: Editora UFMG.

COMISSÃO NACIONAL DO FOLCLORE. Carta do Folclore Brasileiro. Salvador: CNF, 1995. In http://www.fundaj.gov.br/geral/folclore/carta.pdf. Acesso em 21.Jun. 2018.

CORREIO PAULISTANO (1959). "Tradições populares de Minas e S. Paulo". 22 set. .2-3. In http://memoria.bn.br/DocReader/090972_01/6835. Acesso em 17.Jun. 2018.

EMRICH, Duncan (1946). "Folk-Lore": William John Thoms. California Folklore Quarterly. 5(4), 355-374.

GUIA DE LIVROS. "O Escravo de Capela”. Revista Rolling Stone. 23 Out. 2017. Acesso em 20.Jun.2018. In http://rollingstone.uol.com.br/guia/livro/o-escravode-capela/.

GROTH, Otto (2011). O poder cultural desconhecido. Petrópolis: Vozes.

HARRIS, Jason Marc (2008). Folklore and the Fantastic in Nineteenth-Century British Fiction. Farnham: Ashgated Publishing.

LIMA, Rossini Tavares (2003). A Ciência do Folclore. São Paulo: WMF Martins Fontes. LOBATO, Monteiro (2008). O Saci-Pererê - Resultado de um inquérito. São Paulo: Globo.

(1994). Sítio do Picapau Amarelo: O Saci. São Paulo: Brasiliense. (1964). A barca de Gleyre. São Paulo: Brasiliense.

MARTIN-BARBERO, Jesus (2003). Dos meios às mediações: comunicação, cultura e hegemonia. Rio de Janeiro: UFRJ. 
MATANGRANO, Bruno Anselmi; TAVARES, Eneias (2018). O Fantástico Brasileiro: o Insólito Literário do Romantismo ao Fantasismo. Curitiba: Arte \& Letra.

PEREIRA, Lúcia Miguel (1988). História da literatura brasileira: prosa de ficção: 1870 a 1920. São Paulo: Editora da Universidade de São Paulo.

PENTEADO FILHO, José Roberto Whitaker (2011). Os Filhos de Lobato: O Imaginário Infantil na Ideologia do Adulto. São Paulo: Editora Globo.

QUEIROZ, Renato da Silva (1987). Um mito bem brasileiro: estudo antropológico sobre o Saci. São Paulo: Polis.

REGINA, Ivan Carlos (1988). "Manifesto Antropofágico da Ficção Científica Brasileira" Somnium, (30).

ROMERO, Silvio (1885). Contos Populares do Brazil. Lisboa: Nova Livraria Internacional.

TIERNO, Walter (2010). Cira e o Velho. São Paulo: Giz Editorial.

TODOROV, Tzvetan (2008). Introdução à literatura fantástica. São Paulo: Perspectiva.

ORICO, Osvaldo (1975). Mitos ameríndios e crendices amazônicas. Rio de Janeiro: Civilização Brasileira.

ZUMTHOR, Paul (2014). Performance, Recepção, Leitura. São Paulo: Cosac Naify. 